Received 25 November 2012 Revised 21 May 2013

Accepted 13 September 2013

\title{
Organisation and supply chain for quality control in luxury companies
}

\author{
Alessandro Brun and Antonella Moretto \\ Management, Economics, and Industrial Engineering, \\ Politecnico di Milano, Milano, Italy
}

\begin{abstract}
Purpose - The purpose of this paper is to identify the organisation of the quality department and the management of the supply chain (SC) used by luxury companies to achieve quality requirements.

Design/methodology/approach - The paper follows an exploratory approach using a case-based methodology. Data are collected through eight case studies with French luxury companies.

Findings - The paper offers insights into the management of quality for luxury companies. The paper illustrates the main determinants of the adoption of the specific quality organisations; moreover, the paper identifies the main approaches adopted by luxury companies at the SC level to control the quality along the whole chain. For example, the paper raised that all accessible and aspirational luxury companies present a full-time quality department whereas a part-time approach is identified for high-luxury companies. In high-luxury companies, quality issues are perceived as critical elements to be monitored not just by one specific department but by each and every company employees; on the contrary, in the other companies the approach towards quality is more similar to the one of mass-market companies.

Research limitations/implications - The research provides initial insights into the important role of quality in luxury companies. To date, the analysis is predominantly qualitative and not sufficiently statistically significant to generalise the results.

Practical implications - This paper raises a number of important issues for luxury companies who are not advance yet in structurally managed quality issues into their companies but especially their SCs. Originality/value - This paper is one of the first attempts to study quality management specifically applied to luxury companies, with a main focus on the organisation of the quality department as well as the SC.
\end{abstract}

Keywords Organization, Luxury industry, Supply chain, Quality management

Paper type Research paper

\section{Introduction}

For many years, the luxury industry has attracted the attention of researchers who have mainly focused on sociological, marketing (e.g. Vickers and Renand, 2003) and branding aspects (e.g. Atwal and Williams, 2009). Although branding and marketing aspects are fundamental for the achievement of success (Moore and Birtwistle, 2004), these efforts alone are not enough to guarantee long-term sustainable profitability. On the contrary, little attention has been paid to operations and supply chain management (SCM) perhaps because luxury firms sometimes look for voluntary inefficiencies (e.g. manual labour, long waiting lists, etc.) by pursuing competitive advantage over rarity and brand exclusivity (Luzzini and Ronchi, 2010). In particular, very often the literature does not present SCM as strategically important in determining the success or failure of luxury companies, as otherwise happen for other industries.

The authors wish to thank Elfie Meneses, master student of IMIM, for her valuable contribution to this research during case study deployment and analysis. 
Despite such consideration, however, preliminary studies have also highlighted the importance of SCM for luxury companies with a strategic perspective (Brun et al., 2008; Caniato et al., 2009; Luzzini and Ronchi, 2010): in fact, these companies cannot focus only on marketing efforts if they aim to move brands towards a higher positioning and add more valuable features to products and services.

For measuring SCM value, the literature about SCM has highlighted the relevance of not financial indicators, such as quality, cost, service level, and flexibility; among these indicators and by taking into account also the main critical success factors (CSFs) for luxury companies, accordingly with the consideration that SCM should have a strategic relevance in luxury companies, quality appears as one of the most relevant issue to take into account (Brun et al., 2008). The relevance of this link is raised by leading expert of the industry as well; as mentioned by Arnault: "if you do not control your manufacturing you do not control your quality". According to these issues and taking into account the high relevance of quality for $\mathrm{SCM}$, among the existing supply chain (SC) methodologies, total quality management (TQM) might by a relevant area of research in luxury industries, although under investigating in the existing literature, with few notable exceptions: for instance Forker et al. (1997) posit that TQM is the most important input for world-class manufacturing.

Furthermore, we believe that the investigation of TQM management for luxury industry might be relevant also because the concept of luxury does not refer to a single industrial sector but rather cuts across several traditional sectors embracing the top segment within various industries (e.g. automotive, apparel, yachts, leather bags, etc.) (Caniato et al., 2008). Finally several authors have mentioned the influence of contingent variables, such as industry, and SC methodologies on the successful implementation of TQM practices (e.g. Sohal and Terziovski, 2000; Flynn and Flynn, 2005).

According to these considerations, this paper aims to analyse the TQM in the French luxury industry from a twofold perspective. First, according to the relevance of organisational structure for quality as raised by the literature (e.g. Vickery et al., 1999), we investigate how luxury companies organise their quality departments to achieve quality requirements. Moreover, consistent with the fervent debate in the literature about the importance of a SC perspective for quality (e.g. Foster, 2008), our second research goal is to explore how French luxury companies organise their SC for quality improvement. To reach these research goals, eight in-depth case studies of prominent French luxury companies have been conducted.

The Figure 1 illustrates the main steps of the research process followed to define our research questions $(\mathrm{RQs})$.

The paper is organised as follows. In Section 2, we present an overview of the literature that addresses both the relevance of SCM for luxury companies and the main critical elements for TQM. In Section 3, our research goals are formulated and our research methodology is explained. In Section 4, we discuss the findings obtained through the critical cross-case analysis, whereas in Section 5 we present the implications of the study and the generalisability of our results. The present paper is the outcome of a research project going on at Politecnico di Milano, launched by joining two larger - and originally independent - research streams.

In particular the first research stream is focusing on the analysis of current practices - and the development of new ones - along the SCs in luxury companies.

The seminal work of this research stream is the research presented by Brun et al. (2008), which sets the ground for the future development of a new and quite unexplored 
Figure 1.

Steps of the research process

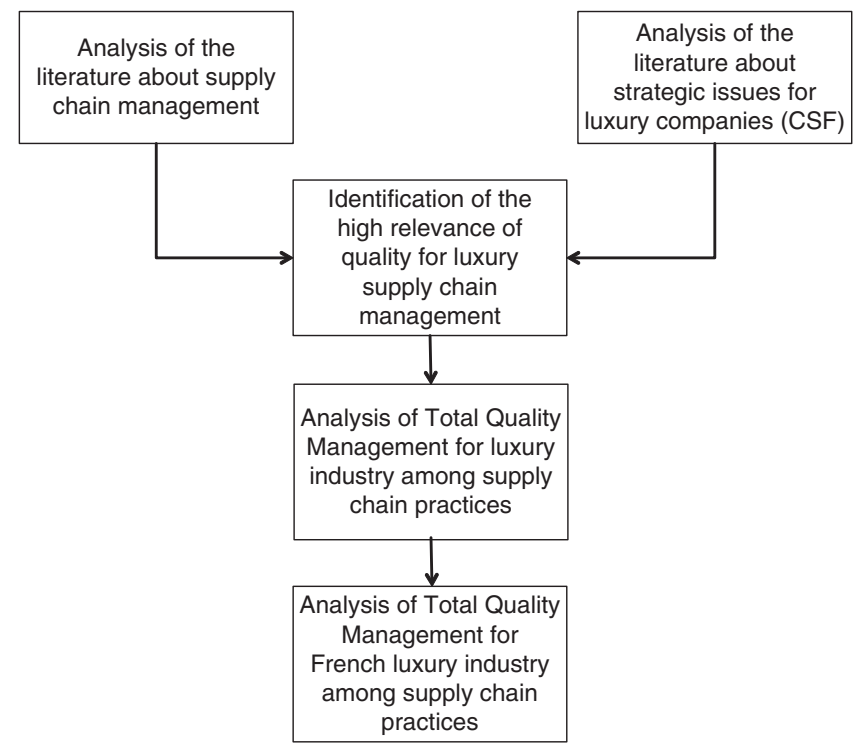

research field; later findings are summarised in Brun and Castelli (2008), focusing on the development of a portfolio approach to manage the fashion SC; Caniato et al. (2009) to explore the applicability of traditional SC models to the luxury field; Castelli and Brun (2010) to study the relevance of retail for Italian fashion companies; Luzzini and Ronchi (2010) to explore the organisation patterns of the purchasing function in luxury companies; and Brun and Moretto (2012) to explore the issue of contracts as a mean to coordinate the downstream SC. The second research stream studies the application of quality management methodologies in companies pertaining to a number of different sectors.

Previous outcomes of this research stream could be found in Cagnazzo et al (2010), Brun (2011), and Savino et al. (2011)

\section{Literature review}

In this paragraph, the main literature review about the relevance of SCM for the luxury industry and about TQM is presented.

For reader's sake, we included in the Table I the main definitions used throughout the paper.

\subsection{SCM in the luxury industry}

There are many studies on SCM in the literature (e.g. Harland, 1996; Croom et al., 2000), but SC models are mainly applied to large-scale mass-market manufacturing industries and have little applicability in the luxury sector (e.g. Caniato et al., 2011). The literature addresses that the luxury industry has different CSFs compared to mass-market companies and so there are different approaches to SCM: as demonstrated by Brun et al. (2008), just a few SCM models could be applied in luxury context as well. However, SCM could be important for luxury companies given that SC configuration and management could impact the CSFs of luxury companies, thereby supporting them in achieving a competitive advantage (Brun et al., 2008; Brun and Moretto, 2012). 


\begin{tabular}{|c|c|c|}
\hline Term & Definition & Reference \\
\hline Supply chain & $\begin{array}{l}\text { A "supply chain" universally encompasses the following } \\
\text { three functions: } \\
\text { (1) supply of materials to a manufacturer; } \\
\text { (2) the manufacturing process; and } \\
\text { (3) the distribution of finished goods through a network of } \\
\text { distributors and retailers to a final customer. Companies } \\
\text { involved in various stages of this process are linked to } \\
\text { each other through a supply chain }\end{array}$ & $\begin{array}{l}\text { www.supply- } \\
\text { chain.org }\end{array}$ \\
\hline \multirow[t]{2}{*}{$\begin{array}{l}\text { Supply chain } \\
\text { management }\end{array}$} & $\begin{array}{l}\text { Supply chain management encompasses the planning and } \\
\text { management of all activities involved in sourcing and } \\
\text { procurement, conversion, and all logistics management } \\
\text { activities. Importantly, it also includes coordination and } \\
\text { collaboration with channel partners, which can be suppliers, } \\
\text { intermediaries, third party service providers, and } \\
\text { customers. In essence, supply chain management integrates } \\
\text { supply and demand management within and across } \\
\text { companies }\end{array}$ & $\begin{array}{l}\text { www.supply- } \\
\text { chain.org }\end{array}$ \\
\hline & $\begin{array}{l}\text { The systematic, strategic coordination of the traditional } \\
\text { business functions within a particular company and across } \\
\text { businesses within the supply chain, for the purposes of } \\
\text { improving the long-term performance of the individual } \\
\text { companies and the supply chain as a whole }\end{array}$ & $\begin{array}{l}\text { Mentzer et al. } \\
(2001)\end{array}$ \\
\hline $\begin{array}{l}\text { Total quality } \\
\text { management }\end{array}$ & $\begin{array}{l}\text { Total quality management (TQM) is a systematic quality } \\
\text { improvement approach for firm-wide management for the } \\
\text { purpose of improving performance in terms of quality, } \\
\text { productivity, customer satisfaction, and profitability }\end{array}$ & ASQ \\
\hline & $\begin{array}{l}\text { Management approach of an organisation, centred on } \\
\text { quality, based on the participation of all its members and } \\
\text { aiming at long-term success through customer satisfaction } \\
\text { and benefits to all members of the organisation and society }\end{array}$ & CQI \\
\hline $\begin{array}{l}\text { Critical } \\
\text { success } \\
\text { factors }\end{array}$ & $\begin{array}{l}\text { CSFs are the few key areas in which favourable results will } \\
\text { ensure successful competitive performance. They represent } \\
\text { the structural variables that most contribute to the } \\
\text { attainment of strategic goals and objectives }\end{array}$ & Rockart (1979) \\
\hline
\end{tabular}

Table I. Definitions

In particular, according to Caniato et al. (2008), the main CSFs for the luxury industry are as follows:

- high level of quality, considering both compliance with specifications and the adoption of superior quality materials;

- heritage of craftsmanship, often stemming from the original designer;

- exclusivity of products, obtained with the use of scarce materials, limited editions, and limited distribution;

- emotional appeal, created during the shopping experience and after sales services;

- brand reputation, known as worldwide excellence;

- recognisable style and design;

- association with a country of origin that is well known for excellence in a specific product category (e.g. silk for Italy); 
- uniqueness, i.e., the presence of unique elements to ensure that the product is not mass-produced; and

- creation of a lifestyle because of the perception of being part of a unique style.

In the list above, quality-related issues are highly relevant.

\subsection{TQM: a special field}

The implementation of TQM implies training at all levels of the organisation, the formation of partnerships along the $\mathrm{SC}$, the control of the statistic process, and the implementation of a real-time production management system to obtain the required information (de Araujo, 1997). In fact, the TQM philosophy implies developing a corporate-wide culture that stresses customer attention, continuous improvement, empowerment, and data-driven decision-making (Kannan and Tan, 2005).

There have been numerous studies on TQM in the last twenty years (e.g. Agus et al., 2000; Anderson et al., 1994; Kaynak and Hartley, 2008), and the empirical research in this area has mainly defined and measured specific quality practices (e.g. Ahire et al., 1996; Flynn et al., 1994; Nair, 2006). Other studies have analysed the linkages among quality practices and company performance (e.g. Kaynak, 2003; Popp et al., 2001; Prajogo and Sohal, 2006; Sadikoglu and Zehir, 2010; Samson and Terziovski, 1999). The majority of this study considers, as a unit of analysis, the manufacturers of finished goods (e.g. Garvin, 1988; Agus and Hassan, 2011).

The awareness of quality issues has increased in the last several years, primarily as a result of the globalisation of markets (Popp et al., 2000). Companies in every sector recognise the key role played by TQM in driving change in modern organisations (Irani et al., 2004; Santos-Vijande and Álvarez-González, 2007).

However, notwithstanding the clear definitions of main concepts, there is still a need for further research in some areas.

First, several authors have mentioned that there is no unique approach to develop TQM inside different companies (e.g. Antony et al., 2002; Fryer et al., 2007; Mar Fuentes-Fuentes et al., 2004; Sila and Ebrahimpour, 2003; Sohal and Terziovski, 2000). According to this school of thought, several contingent elements could dramatically affect the implementation of TQM inside organisations. Some authors have addressed the importance of corporate culture (Corbett and Rastrick, 2000; Maull et al., 2001; Naor et al., 2008; Rad, 2006), while others have emphasised the importance of soft skills, such as management leadership and employee relations and stakeholder pressures (Berman et al., 1999; Lewis et al., 2006; Kaynak and Hartley, 2008). Still others focus on the role of the organisational structure (Vickery et al., 1999). Although the literature has highlighted some interesting areas, additional research might be necessary in this research vein.

Second, recent attention to SCM has urged companies towards a redefinition of models and constructs for TQM. Models were, in fact, originally developed for the field of operations management, and accordingly, they are currently being re-shaped to consider both internal and external processes (Flynn and Flynn, 2005; Kuei et al., 2008). In this new instance, the concept of supply chain quality management (SCQM) was introduced by scholars as "a system-based approach to performance improvement that leverages opportunities created by upstream and downstream linkages with suppliers and customers" (Foster, 2008; Robinson and Malhotra, 2005). However, even though there is a trend towards SCQM, the main features that lead to achieving it have not yet been fully explored. Moreover, given that both SCM models and TQM are affected by some contingencies related to the characteristics of both the individual company and 
the specific industry (e.g. Agus, 2001; Popp et al., 2000), specific analysis for an industry must be performed. Despite some authors (e.g. Forker et al., 1997) hinted the importance of TQM for luxury companies, the literature is still poor of contributions that specifically investigate this issue.

\section{RQs and research methodology}

\subsection{Research objective}

The literature review thus far demonstrates the crucial relevance of quality issues for luxury companies, despite the lack of studies in this area. Moreover, an SC approach to study quality was noted, though few studies have adopted this perspective. Finally, several authors (e.g. Maull et al., 2001; Kaynak and Hartley, 2008; Vickery et al., 1999) have addressed the critical role of contingencies, such as industry and organisation, on quality achievement despite the lack of literature on this school of thought.

Accordingly, the objective of this paper is to determine how the quality department in French luxury companies is generally organised and how the quality system is managed to ensure the quality of the final products. This paper investigates whether French luxury companies show specific patterns compared to the usual schemes concerning quality departments due to the differences and the important requirements of this sector with respect to quality.

According to this overall objective, two more detailed RQs have been formulated. The first RQ is specifically dedicated to investigate the organisation of the quality control department. Given that some authors (e.g. Irani et al., 2004) maintain the relevance of organisational characteristics to achieve high quality and given that the quality is a CSF for luxury companies (Caniato et al., 2008), our first RQ is as follows:

$R Q 1$. How do French luxury companies organise their quality department to satisfy quality requirements of the industry?

The literature suggests that quality is achieved not only with a coherent internal organisation but also by implementing a SC approach (e.g. Foster, 2008). Entities such as external suppliers and retailers play an important role in the achievement of the quality requirements (Kaynak and Hartley, 2008). According to this consideration, we ask the second $\mathrm{RQ}$ :

$R Q 2$. How do French luxury companies manage their SC to satisfy quality requirements of the industry?

\subsection{Research methodology}

Given the exploratory nature of the topic, a case-based methodology was selected (Yin, 1994). Case study research has interpretive advantages even though it is limited in terms of the standardisation and generalisation of findings outside the boundaries of the specific empirical research (Larsson and Lubatkin, 2001). Furthermore, case studies allow to accumulate sufficient knowledge to lead to understanding or explaining phenomena in their natural setting (Lincoln and Guba, 1985) and allow the researcher to delve into the respondents' mental world (McCracken, 1988). Moreover, case research is, therefore, useful and to be used when the investigated phenomenon is broad, complex, and not possible to be studied outside the context in which it occurs.

In particular, we carried out eight case studies of French luxury companies. This number can be considered sufficient to provide an accurate account in empirical 
research (Yin, 1994; Eisenhardt, 1989). French companies were selected because of the paramount role they play in the luxury segment of sectors such as jewellery, haute couture, wine and spirits. The case selection strategy was driven by the desire to analyse representative cases, for both company and industry peculiarities (Seuring, 2008; Yin, 2003). To maximise the utility of information from the cases, this has been selected on the basis of expectations about information content, thus following the information-oriented selection approach (Flyvbjerg, 2006). Due to the relevance and the importance of the selected companies, these might be said representative of the French luxury industry. Furthermore, representative companies were selected for different contingent variables, according to the purpose of having a heterogeneous sample.

The choice of focusing just on French companies is based on the consideration that the world luxury market is worth more than $\$ 130$ billions and France is the country which owns the largest number of companies in the luxury and historically always been trend setter in the luxury market (source: Luxury Industry in France, StudyMode.com, 2012). Moreover, more so than other countries, France is predisposed for the success of the luxury company for two main reasons: the art craft, perfection and companionship tradition has built a line of remarkable craftsmen, and the citizens hold a capacity to imagine, create, and conceive.

The sample is heterogeneous for product positioning (i.e. accessible, aspirational, luxurious) and for product (i.e. leather goods, cosmetics and perfumes, glass, wines and spirits, jewellery) according to the main characteristics of the luxury industry. On the other hand, plainly the sample is homogeneous in terms of country of origin (France). A single country has been analysed according to some empirical studies (e.g. Rungtusanatham et al., 1998) that have addressed the influence of country on QM effectiveness (following studies will address other countries, e.g. Italy), thus avoiding contamination of results for this variable. Table II summarises the main features of the sample: data included in the Table II have been collected through companies' web sites for what concerns number of employees, turnover and product whereas information collected during the interviews were used to catalogue the company in terms of product positioning and craftsmanship. Data about companies' contingencies were thereby collected by using the direct insights provided by the managers as well as through the support of secondary sources of information, to triangulate the data and to assure the validity of the piece of information.

Interviews were conducted during 2011. Most interviews were conducted face-to-face, though a few were conducted over the telephone. Quality managers and control managers were interviewed in each company. Interviews were semi-structured;

Table II. Sample

\begin{tabular}{|c|c|c|c|c|c|}
\hline Company & Employees & $\begin{array}{l}\text { Turnover } \\
\text { (million } € \text { ) }\end{array}$ & Product & $\begin{array}{l}\text { Product } \\
\text { positioning }\end{array}$ & Craftsmanship \\
\hline Louis Vuitton & 13,700 & 2,500 & Leather goods & Aspirational & High \\
\hline Hermes & 8,370 & 2,401 & Leather goods & Absolute & High \\
\hline Chanel & 1,270 & 1,809 & Cosmetics and perfumes & Aspirational & Low \\
\hline Givenchy & 157 & 100 & Cosmetics and perfumes & Accessible & Low \\
\hline Dior & 76,000 & 21,120 & Cosmetics and perfumes & Accessible & Low \\
\hline Baccarat & 1,870 & 100 & Glass & Aspirational & Medium \\
\hline Moët \& Chandon & 1,169 & 603 & Wines and spirits & Accessible & Low \\
\hline Cartier & 300 & 2,000 & Jewellery & Absolute & Medium \\
\hline
\end{tabular}


i.e., the interviewee received a list of topics but was free to discuss topics from a personal perspective. The questionnaire was composed of three main parts:

- the perception and perspective of quality and its relative importance, aiming at understanding the meaning of quality and the importance of quality for the company;

- the responsibility of quality, aiming at understanding the organisational structure of the quality department in terms of organisational chart, level of centralisation, size of quality control department, level of control, roles and responsibilities; and

- the management of quality, aiming at understanding the focus on quality at the $\mathrm{SC}$ level in terms of production activities (TQM, certifications, quality manual, etc.), suppliers, distribution and point of sales.

Beyond interviews, direct observations during company visits and secondary sources of information were also used to perform data triangulation. All data collected were catalogued in a structured database and standardised to perform a qualitative data reduction according to the main categories identified in the research framework and suggested by the literature. The qualitative data reduction had the goal of increasing the comparability of the information, by reducing the number of data to simultaneously take into account. A within- and cross-case analysis has been performed to identify the main patterns in terms of quality organisation inside the company and across the SC. First of all, the qualitative data were coded according to the variables identified with the literature review for achieving data reduction as well as facilitating the replication of the study. Then, each case was singularly analysed to identify main peculiarities and limitations. Each researcher involved in the study individually analysed each case and results were shared to get a common interpretation: this step was replicated until all of the researchers arrived to a common view of the single case study. The within-case analysis has been oriented to identify the main features of each case in terms of organisation of quality department, role of quality department and management of the SC for quality improvement.

After that a cross-case analysis was performed to bring out the main commonalities among the different cases as well as the peculiarities of each of them. All the cases were compared for each single variable of the research framework, with the purpose of understanding which are the commonalities among cases and which could be the drivers behind these commonalities. Focusing on one specific country and a single industry we could compare companies that deal in a similar contexts with similar features highlighting differences in terms of configuration of the quality department. We interpreted the results under the light of the information collected in the cases and the insights provided by the literature analysis that helped to identify and marginalise the impact of the business environment. Once the cross-case analysis was performed, a detailed transcription of the company was sent to the interviewee to be sure to have obtained a realistic impression of the company and not having misinterpreted any information.

\subsection{Research variables}

To answer each of our RQs, the following variables have been considered.

For the first $\mathrm{RQ}$, the features of the organisation of the $\mathrm{QM}$ department are measured (see Table III). In particular, this element is analysed from a twofold perspective, i.e., the structure of the department and the role of the department (quality control) (Vickery et al., 1999). 


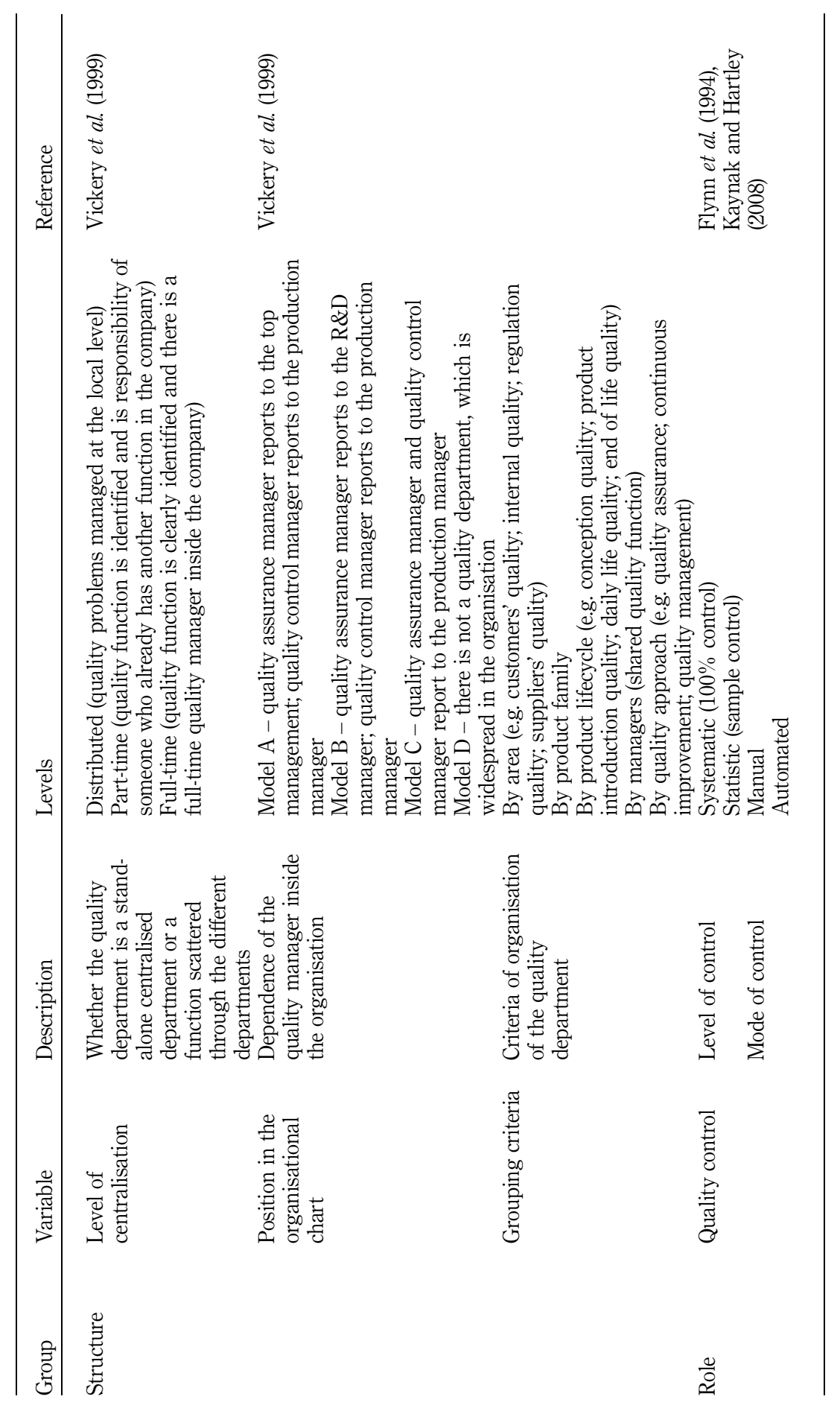

Table III.

Variables for organisation of quality department 
For the second RQ, we focused on those $\mathrm{SC}$ elements regarded as paramount for assuring a high level of quality (see Table IV). In this case, the main SC processes (i.e. make, source, and deliver) were taken into account, according to the main SC processes suggested by the SCOR model (source: www.supply-chain.org). These processes were included in order to understand their influence on the external quality of the company.

Considering the make process, the internal procedures used to control the quality inside the company and, in particular, within the manufacturing activities are analysed. Such procedures are extremely relevant, as the TQM first focuses on the manufacturing process and then on the implementation of quality both upstream and downstream in the SC (Fawcett et al., 2006).

According to this consideration, we also regarded the sourcing process as an important element of quality (Forker et al., 1997) due to the manifest strategic relevance of raw materials in luxury (Luzzini and Ronchi, 2010), thus compelling us to reconsider the suppliers beyond the classical definition of the specialty. Accordingly, one of the main objectives of supplier integration is to exert stronger control over the manufacturing process and to ensure the know-how and the quality that legitimise the brand.

Finally, the delivery process must be considered as it too plays a relevant role in TQM and must be carefully managed (Caniato et al., 2011).

Finally, some contingent variables have been considered in the analysis to identify whether they could help discriminate among different companies' behaviours (see Table V). The contingent variables have been included because some studies (e.g. Benson et al., 1991; Zhao et al., 2004) revealed that not every single TQM practice could be effectively applied in all companies. The contingent variables considered correspond to the main features of the luxury industry (different product categories and different categories of luxury) and to luxury CSFs that are strongly

\begin{tabular}{|c|c|c|c|}
\hline Group & Variable & Measure & Reference \\
\hline \multirow[t]{3}{*}{ Make } & Formalisation & $\begin{array}{l}\text { Certification (none/"internal" certification/ } \\
\text { industry certification/country certification/ } \\
\text { volunteer certification) }\end{array}$ & Foster (2008) \\
\hline & & Documentation (none/procedure/manual) & $\begin{array}{l}\text { ISO 9000: } 2000 \\
\text { set of standard }\end{array}$ \\
\hline & $\begin{array}{l}\text { Application } \\
\text { of TQM }\end{array}$ & $\begin{array}{l}\text { No formalised application/formalised } \\
\text { application }\end{array}$ & Irani et al. (2004) \\
\hline Source & $\begin{array}{l}\text { Supplier quality } \\
\text { assurance }\end{array}$ & Adopted/not adopted & \\
\hline \multirow[t]{2}{*}{ Deliver } & Type of network & Multi-brand network/owned network & $\begin{array}{l}\text { Moore and Birtwistle } \\
(2004)\end{array}$ \\
\hline & Level of control of & Autonomous/low control/tight control & Foster (2008) \\
\hline
\end{tabular}
the network

Table IV. Variables for quality along the SC

\begin{tabular}{lll}
\hline Variable & Measure & Reference \\
\hline Product category & $\begin{array}{l}\text { Leather goods, cosmetics and perfumes, } \\
\text { glass, wines and spirits, jewellery }\end{array}$ & Caniato et al. (2008) \\
Category of luxury & $\begin{array}{l}\text { Absolute/aspirational/accessible } \\
\text { Craftsmanship }\end{array}$ & Low/medium/high
\end{tabular}

Table V. Contingent variables 
related to quality (craftsmanship). Details about companies for those variables can be found in Table II.

\section{Results and discussion}

\subsection{The organisation of the quality department}

This subsection aims at presenting the cross-case analysis (see Appendix 1 and summary in Table VI) oriented to identify common patterns in the organisation of the quality department in French luxury companies and to find criteria for clustering different approaches through company similarities in terms of control variables.

We summarised in the Table VII the main results illustrated in the next paragraphs.

4.1.1 Structure of the quality department. The cross-case analysis shows the strong relevance of the category of luxury in discriminating among different organisations of the quality department. The category of luxury appears to have an impact on both the level of centralisation and the position of the quality department on the organisational chart.

In fact, all accessible and aspirational luxury companies have a full-time quality department, whereas a part-time approach is identified for high-luxury companies (i.e. Hermes and Cartier). In high-luxury companies, quality issues are perceived as critical elements to be monitored not just by one specific department but by each and every company employees, as suggested by Forker et al. (1997): quality issues should perceived the whole organisation, without any functional silos. On the contrary, in the accessible luxury companies, the approach to quality is more similar to that of massmarket companies: in this case, quality is mainly a matter of the quality department and is not a widespread phenomenon, which entails all the organisation.

For what concerns the position in the organisational chart, all of the four possible cases are represented in the sample:

- Chanel and Dior represent model A, which addresses a double dependency of the quality manager. For instance, the quality assurance manager in this case reports directly to the top management, while the quality control manager reports to the production manager. This model assures both strategic and operational attention to quality issues.

- Model B is implemented by Moët \& Chandon, which might be considered a peculiar case as the company has two different and nearly independent quality departments. The first one - the wine quality department - is brand oriented and has a quality expert responding to the cellar leader for each brand. The second one manages quality at the production level, thus directly reporting to the production department.

- Model C is adopted by Louis Vuitton, Givenchy, and Baccarat. These companies do not have an independent quality department, as the quality operations are reporting to the industrial department. The latter structure is dedicated to the production site for Baccarat, whereas the department is centralised in Louis Vuitton.

- Model D is adopted in Hermès and Cartier. Hermès has a widespread quality department that is tightly merged with the company's industrial activities, whereas Cartier's quality department is merged with the customer service department.

By comparing the different contingent variables in the sample, the level of luxury proves to be a variable in discriminating among different positions of the quality department in the organisational chart. As shown in Figure 2, we found that all of the high-luxury companies adopt model D, while companies with aspirational luxury 




Table VI. Summary of the cross-case analysis - organisation of the quality department 


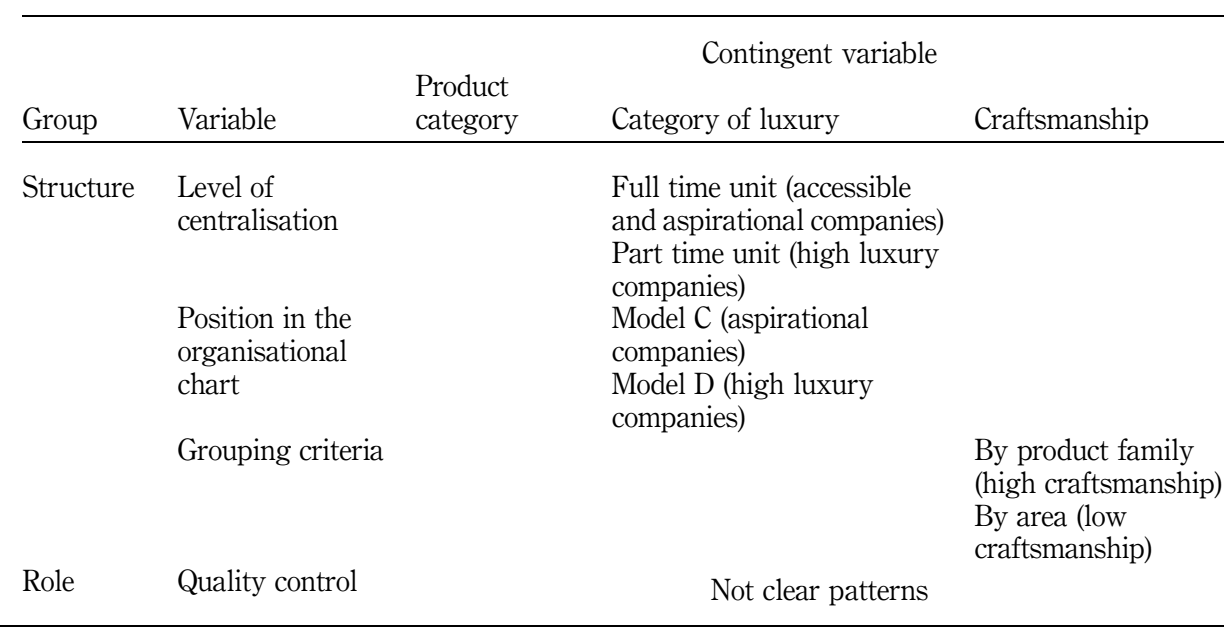

Figure 2.

Position in the organisational chart compared to the level of luxury

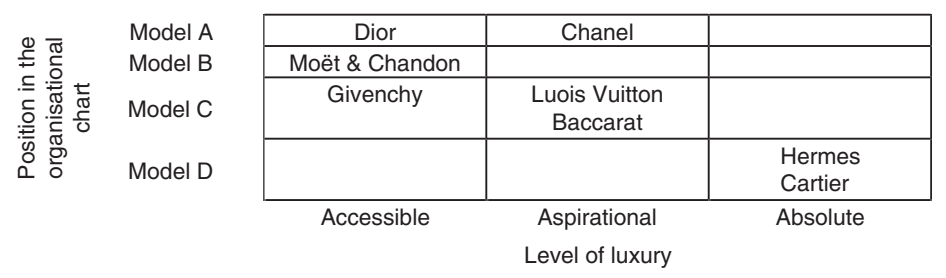

prefer model $\mathrm{C}$. However, there is significant variety in model adoption regarding the concerns of the accessible companies. This result is quite unexpected, as those companies whose quality issues are more relevant (high-luxury ones) appear to adopt an overall less structured approach to TQM.

On the other hand findings related to the quality department structure could be summarised as follows:

- The most frequently adopted approach is by area. The perfumes and cosmetics companies are structured by area, with a quality department dedicated to the production sites that manages the different quality activities, such as quality control, quality assurance, quality systems, customer service, and so on. Givenchy, Dior and Chanel follow this approach. The glassmaker Baccarat, for which the quality department is directly tied to the production site, clusters their quality department following the same path as Givenchy, with no central department. As such, the activities of operational control and quality assurance are in distinct entities, but both are in the production site's quality department. Moët \& Chandon also follows the structure by area for the industrial quality department; however, the group has another quality department that is structured "by product family", with an expert for each type of wine produced.

- A few companies adopt a criterion-by-product family. The enterprises based on leather trade - Hermès and Louis Vuitton - arrange their quality department following a product family organisation concept. This can be explained by the fact that the focal activity is the leather work, and other activities have been 
developed around it. Accordingly, the organisation has been naturally tailored to these different trades developed over time. Moreover, because this activity is still very artisanal, the quality control is not fully managed by a part of the QM department but remains mostly in charge of the craftsmen themselves.

- Cartier, which is leading the group in terms of most modernised production system and methods, is the only company clearly demonstrating structure by approach. Indeed, it clearly has two roles for the quality departments: quality assurance and improvement process.

- In the sample, no examples of grouping criteria by managers and by product lifecycle have been noted.

The relevance of the craftsmanship appears an interesting variable for the impact on grouping criteria. As shown in Figure 3, there are clear approaches followed by the companies with either high or low levels of craftsmanship. Companies with a high level of craftsmanship, such as Louis Vuitton and Hermès, adopt a grouping criterion by product family, thus increasing and maximising the product and technical knowledge as well as addressing quality issues. On the contrary, companies with a low level of craftsmanship are organised by area, where high-process industrialisation emphasises the relevance of quality in each step of the process. Finally, no significant patterns could be identified for companies with a medium level of craftsmanship, perhaps because they are currently in an intermediate and transitory situation.

4.1.2 Role of the quality department. The cross-case analysis emphasises that different types of control are used in the French luxury sector. Some companies, such as Dior and Chanel, employ a classical control methodology based on statistics and sampling, and they automate it as much as possible. In these cases, the process is quite similar to any other industry. On the other hand, there are companies, such as Baccarat and Moët \& Chandon, that incorporate a systematic and automated approach. Baccarat, which is divided between the will of industrialisation and the traditional requirements of glass working, shows this double aspect in the controls applied; the luxury requirements imply a systematic control, while in cases of industrial-scale production an automated approach is typically advocated. In the wines and spirits field, the control is automated but very strong, given the regulatory requirements in this sector. Accordingly, systematic control is in place in Moët \& Chandon, where there are several controls enforced during the manufacturing process with up to a 100 per cent inspection of final products. The cases of leather companies are quite interesting. In the case of Louis Vuitton, all finished products are controlled by a third person following a specific protocol. With respect to Hermès, there are no inspectors at all, as craftsmen are directly responsible for the quality of the finished products. Finally, two companies are following hybrid approaches. Givenchy follows the same

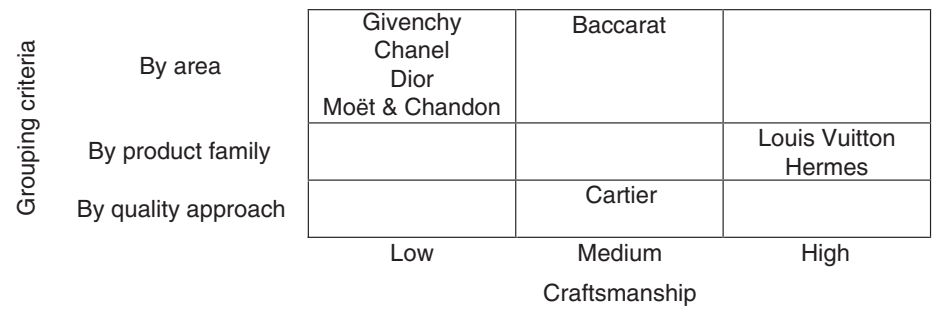

Figure 3.

Grouping criteria compared to craftsmanship 
approach of other cosmetic companies, namely, statistical sampling, for most of the products, but for haute couture, they adopt a systematic control. Similar behaviour could be mentioned for Cartier, which uses systematic control only for its fine jewellery. However, even if methods and levels of control vary among the different activities, a clear and consistent trend is the importance of exerting this control due to the higher requirements of quality related to the luxury field.

No clear patterns can be identified for the role of the quality department, particularly with respect to level of control (see Figure 4). Regarding the mode of control, Louis Vuitton, which has a high level of craftsmanship, is the only company where control is carried out manually. Hermès, the other company with a high degree of craftsmanship, does not employ any formal method of control. This result may be driven by the low level of maturity of luxury companies in adopting TQM practices, such as the ones considered. Accordingly, no clear patterns can yet be identified in the French industry. A longitudinal analysis to compare the behaviour in the near future may be meaningful to improve this evidence.

Finally, by considering the product categories taken into account in our investigation, the product category seems not to have a significant impact on the approach to TQM. In considering all of the companies with a high level of technical features regarding the products, no clear patterns could be identified: additional analyses might be necessary in the future to test this issue in a statistical sample, to verify with a larger sample of analysis and by considering several product categories the result.

\subsection{The management of the SC for quality improvement}

The cross-case analysis (see Appendix 2 and summarised in Table VIII) to determine common patterns in the management of the SC for quality improvement in French luxury companies aims to identify the criteria grouping different approaches through company similarities in terms of control variables.

We summarised in the Table IX the main results illustrated in the next paragraphs.

4.2.1 Quality in the "make" process. While the ISO certification for the TQM system (ISO 9000) is often not regarded in the luxury field, other certifications are adopted depending on the specific needs of each activity:

- Some French luxury brands have incorporated a quality certification programme because of regulatory requirements. For example, luxury brands in the cosmetics field may adopt certain pharmaceutical standards for international compliance (e.g. Chanel and Givenchy).

- Other specific norms can be followed to guarantee the quality-specific products, such as the norms for the lamps that are used in Baccarat. This is also the case with Moët \& Chandon, which obtained certification for food safety. However, norms and product certifications are most often adopted for exportation, as they must comply with the regulations of other countries so that the products can be accepted abroad.

Figure 4.

Role of the quality department

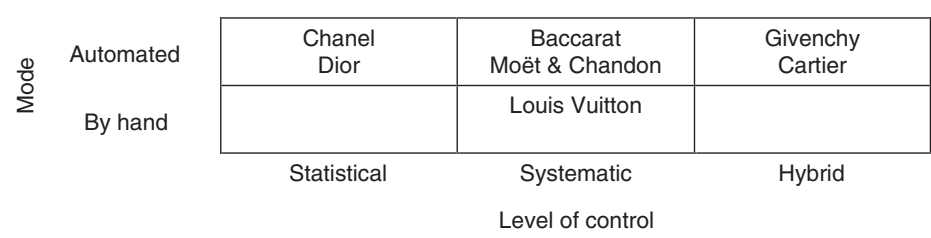




\begin{tabular}{|c|c|c|c|c|}
\hline Group & Variable & Measure & Cases & \\
\hline \multirow[t]{15}{*}{ Make } & Formalisation & None certification & Hermes & \\
\hline & & Internal certification & $\begin{array}{l}\text { Dior } \\
\text { Cartier }\end{array}$ & \\
\hline & & & Givenchy & \\
\hline & & Country certification & Baccarat & \\
\hline & & & Moët \& Chandon & \\
\hline & & Volunteer certification & $\begin{array}{l}\text { Louis Vuitton } \\
\text { Moët \& Chandon }\end{array}$ & \\
\hline & & None documentation & Hermes & \\
\hline & & Procedure & Givenchy & \\
\hline & & & Baccarat & \\
\hline & & & Cartier & \\
\hline & & Manual & Chanel & \\
\hline & & & Baccarat & \\
\hline & & & Moët \& Chandon & \\
\hline & Application of TQM & No formalised application & All of the companies & \\
\hline & & Formalised application & na & \\
\hline \multirow[t]{8}{*}{ Source } & Supplier quality assurance & Adopted & Chanel & \\
\hline & & & Givenchy & \\
\hline & & & Dior & \\
\hline & & & Cartier & \\
\hline & & Not adopted & Louis Vuitton & \\
\hline & & & Hermes & \\
\hline & & & Baccarat & \\
\hline & & & Moët \& Chandon & \\
\hline \multirow{10}{*}{ Deliver } & Type of network & Multi-brand network & Chanel & \\
\hline & & & Givenchy & \\
\hline & & & Dior & \\
\hline & & & $\begin{array}{l}\text { Baccarat } \\
\text { Moët \& Chandon }\end{array}$ & \\
\hline & & Owned network & Louis Vuitton & \\
\hline & & & Hermes & \\
\hline & & & Baccarat & Table VIII. \\
\hline & & & Cartier & Summary of the cross-case \\
\hline & Level of control of the network & Autonomous & Hermes & analysis - management \\
\hline & & $\begin{array}{l}\text { Low control } \\
\text { Tight control }\end{array}$ & $\begin{array}{l}\text { All of the other companies } \\
\text { Louis Vuitton }\end{array}$ & $\begin{array}{r}\text { of the } \mathrm{SC} \text { for quality } \\
\text { improvement }\end{array}$ \\
\hline Group & Variable & Result & & \\
\hline \multirow[t]{3}{*}{ Make } & Formalisation & \multirow{2}{*}{\multicolumn{2}{|c|}{$\begin{array}{l}\text { Not widespread } \\
\text { Driven by external drivers (e.g. industry, host } \\
\text { country regulation, customers requirements) }\end{array}$}} & \\
\hline & & & & \\
\hline & Application of TQM & \multicolumn{2}{|c|}{ Low adoption of manuals and documentation } & \\
\hline Source & $\begin{array}{l}\text { Supplier quality } \\
\text { assurance }\end{array}$ & \multicolumn{2}{|l|}{ Adopted } & \\
\hline \multirow[t]{2}{*}{ Deliver } & Type of network & \multirow{2}{*}{\multicolumn{2}{|c|}{$\begin{array}{l}\text { Multi-brand network } \\
\text { Low control }\end{array}$}} & \\
\hline & $\begin{array}{l}\text { Level of control of the } \\
\text { network }\end{array}$ & & & $\begin{array}{r}\text { Table IX. } \\
\text { Results of } R Q 2\end{array}$ \\
\hline
\end{tabular}


- The respect of environmental and social requirements is becoming much more important, especially for the luxury customer. That is why some French luxury companies are targeting the ISO 14000 standard, which shows their commitment to environmental matters.

- Cartier decided to introduce an internal certification and auditing system, totally tailored to the firm needs.

With the make perspective, the introduction of certifications is not widespread in the French industry, and external constraints, such as industry and country mandatory certifications, appear to be the real driver for companies. Additionally, in the case of voluntary certifications, the real drivers appear to be external, such as customer requirements, rather than being internal and oriented towards a structured approach to increase quality.

The freedom from formalisation and administrative matters is also manifest in the quality documentation systems used in the French luxury industries. The quality manual is definitely not a standard (adopted by, to a lesser extent, Chanel, Baccarat, Moët \& Chandon); nonetheless, the working documents for the workshops are almost systematic. For example, Louis Vuitton is reviewing its quality documentation to formalise it with the aim of making it easier to use rather than for the purpose of adhering to regulations. However, the basic idea of Louis Vuitton is that it is not relevant to formalise "more"; rather, it is much more important to formalise "better", that is, to actually provide useful directions for the day-by-day job. Companies such as Givenchy and Dior have a stronger documentation system, especially with respect to the production site.

Finally, as evidenced in the cases herein, a number of French luxury companies remain totally resistant to the application of TQM as such. For example, Hermès is following a completely different approach compared to the TQM mind-set and philosophy, whereas others have accepted the emergence and the spread of this method:

- Givenchy and Dior include the basic principles of the TQM philosophy in the heart of their strategy.

- Chanel promotes management by quality.

- Cartier is fully involved in the re-engineering of the processes for a more widely spread quality throughout the company.

- Baccarat supports the application of TQM but is limited by the craftwork.

- Louis Vuitton, which has not formally adopted TQM, has a quality manager who is strongly influenced by TQM due to his previous professional experience at Toyota.

- Moët \& Chandon has a quite different view and shows little interest in TQM. For example, in terms of a quality mindset and culture, it appears that the company is interested in exerting minimum effort and implementing only that which is strictly required.

The increased habit of giving the responsibility to conduct quality controls and assessments to specific departments, as in the cases of Givenchy, Moët \& Chandon, Dior and Baccarat, as well as Hermès through the product validation by the artisans themselves, shows a determination to involve the whole production workforce in the quest for continuous quality improvement. This is a first step forward for TQM, which 
strives to involve the entire enterprise in its quest. Nevertheless, in spite of the widespread value placed on TQM, none of the companies adopted TQM in a formal way, and some companies are not at all interested in the issues raised by TQM. According to the literature (e.g. Irani et al., 2004), the case of Louis Vuitton has demonstrated the critical role played by internal managers in the diffusion of a quality culture throughout the organisation. That is, the hiring in the company of a quality manager with past experience with Toyota has strongly increased the company's focus on these issues.

4.2.2 Quality in "source" process. In those French luxury companies whose manufacturing processes are still largely based on craftwork, such as Louis Vuitton, Hermes, and Baccarat, the suppliers are often enterprises that are even smaller than the luxury companies themselves, which are already small and medium enterprises. The quality control those companies impose on their suppliers varies widely. As a general rule, they apply the same type of rules and control as those applied in their own internal activities. Indeed, Hermès does not exert a strict control on their suppliers, and this is in line with how they treat their craftsmen: each one has to do his or her own job and must only follow the general guidelines in terms of highquality expectations. The rest (e.g. how you carry out your work and how you check the quality of the output) is simply a matter of trust. In contrast, Louis Vuitton, which is very focused on system management, exerts a strong control and helps suppliers to develop their processes in order to continue increasing quality. Baccarat applies simple statistical control. On the other hand, all of the perfumes and cosmetic companies are implementing a quality assurance scheme for their supplier deliveries, with the aim of lightening the incoming control costs. They are controlling the goods using acceptable quality levels[1] and aim to lighten or even eliminate supplier control. Chanel is at the end of this process and no longer controls incoming goods. Cartier is also focused on the implementation of an acceptance sampling system in order to avoid demanding and costly controls at receipt.

By summarising, the relevance of the $\mathrm{SC}$ for improving internal quality is quite well recognised for the sourcing process in French luxury companies. This relevance is confirmed by the consideration that, in the luxury industry, the main focus of quality control is on incoming inspections. Thus, the term "quality assurance" in luxury is basically a byword for "incoming raw material quality inspections". This is the case for all the companies interviewed, except Hermès, which does not exert any control on its supplier deliveries at all. In particular, the strong adoption of supplier quality insurance checks is typical of all companies with a low level of craftsmanship.

4.2.3 Quality in "deliver" process. Regarding the cases study, we can see that Louis Vuitton, Hermès, and Cartier are only selling in their direct operated stores (DOS). Perfumes and cosmetics (i.e. Dior, Chanel and Givenchy) as well as champagne and wines (Moët \& Chandon) are distributed through a wider network of independent multi-brand stores. It is therefore more difficult for the latter to control the points of sale activities and processes, as stores are independent and manage a number of brands with different positioning and quality standards.

Usually, French luxury companies prefer to have their own DOS in order to control customer service, which is essential to quality and plays an important role in the brand image. As suggested by Arnoult, "if you control manufacturing you control quality; if you control distribution you control image". Then, the local store management is more or less autonomous, depending on the strategy of the company. Hermès even lets stores decide what product range they want to sell. However, the cross-case analysis suggests 
that almost all of the companies, except Louis Vuitton and Hermès, have too low of a level of control over their distribution network.

Based on these insights, we can argue that French luxury companies are not aware of the critical role played by delivery processes with respect to the quality of their company, as demonstrated by the mainly adoption of multi-brand distribution networks.

\section{Conclusions}

In the present paper, we discussed how French luxury companies organise their quality department and manage quality control and quality improvement activities. The analysis has been conducted through eight in-depth case studies of French luxury companies. The main outcomes of this research are that there seems to be no "one best way" approach to organise the quality departments in the French luxury industry. Indeed, the levels of luxury and craftsmanship bring select structures of the quality department and, to some degree, different roles for the department. Globally, French luxury companies are becoming more aware of TQM techniques developed and widely adopted in other industries, such as the automotive industry. Nonetheless, the needs and wills of these French luxury companies vary from one company to another. As shown by our case study analysis, a group of apparently similar French manufacturers of luxury goods, there is not a common way to apply TQM methodologies and approaches. Specific situations may be widely different, from the full implementation of a formalised process through the company (Cartier) to an informal process in which quality is implicit but, nevertheless, an evident requirement (Hermès) and includes the implementation of a quality cell focused on quality control (Louis Vuitton).

In mass-market companies, the implementation of quality control may be mainly a matter of rigor and conformity to specifications, while for French luxury companies, especially when craftsmanship is a CSF, quality is synonymous with variability and uniqueness, and it is obtained as a result of intense attention to details and finishing touches. According to this mindset, higher quality must be demanded without hindering the flexibility and creativity of people. One key concept raised by Louis Vuitton is the importance of identifying different approaches to formalisation; that is, it is not crucial to foster more formalisation but better formalisation. From this perspective, some companies address the low relevance of certification for luxury products, arguing that the key certification is the one granted directly from the customer rather than from external entities.

However, to achieve the required level of quality without enforcing a tight and nonprofitable formalisation, the role of external supplier is of fundamental value because the long-term relationships with suppliers, consistent with the main principles of TQM (de Araujo, 1997), are the key leverages to boost the continuous improvement of quality.

The cases suggest that companies are totally aware of the importance of quality as a widespread concept inside their own organisation, though they are not always able to deeply implement the concept of "everyone's responsibility" (Forker et al., 1997), especially when considering the SC partners, such as distributors and retailers.

Summarising the main suggestions gathered through the case studies, the main point for French luxury companies is to move from product quality to a company that produces quality.

Unexpected as it might be, the product type does not really appear a discriminant issue in our analysis, by reinforcing the importance of considering luxury as a metasector, with high commonalities among different industries. As a matter of fact, none of the decisions about TQM taken into account in our framework is apparently driven by 
the product category; given that, just a small number of product categories were compared, future steps of the study will be devoted to verify and test with a statistical sample this hint; thereby being able to compare several product categories, at the limit to all of the product categories under the luxury umbrella.

The present paper fills the gap in the literature by discovering the main determinants of different organisations' quality departments and the main elements of the SC for quality purposes. The model can be considered a good representation of reality in the French industry given that almost all the variables identified are actually found in the real cases. Accordingly, this consideration suggests a good level of applicability of the model in a real-world context. Moreover, we empirically examined contingent variables, which is cited as one of the most important areas for future research. This represents an important step forward in the identification of contingency discrimination in terms of TQM as well as for the importance of the SC for French luxury companies.

This study also contains valuable contributions for practitioners, helping managers in identifying the most frequent configurations in comparable companies and the main pitfalls in the current TQM practices of French luxury companies.

Some limitations of the present paper should be mentioned. First, the companies are very different from each other, and other product categories typical of the luxury industry, such as automotive and furniture, are not considered in the sample. Moreover, limitation as well as value of the present study, only French companies are considered, without comparison to other countries, thereby not allowing generalisation of the results to other countries. For future research, a cross-country analysis would be helpful to identify the influence of cultural elements on the organisation of the quality department and the SC for quality purposes, although the authors have expectations of finding quite similar results at least for what might concerns the Italian level. Moreover, a focus on specific product categories would be valuable to increase the comparability among data, thus considering more accessible products. Furthermore, future developments could also include the perspective of partners perspective, to consider whether quality procedures are perhaps not included in the process control whereas are included in the partner selection strategy: the consideration of quality issues in the selection of suppliers as well as retailers might be included in the analysis as well. Finally, the results presented in the paper may strongly vary in the future. The present study should be replicated in the next year with a longitudinal perspective to trace the evolution of the industry.

\section{Note}

1. This is the common, informal way to refer to the ISO 2859 for acceptance sampling.

\section{References}

Agus, A. (2001), "A linear structural modelling of total quality management practices in manufacturing companies in Malaysia”, Total Quality Management, Vol. 12 No. 5, pp. 561-573.

Agus, A. and Hassan, Z.F. (2011), "Enhancing production performance and customer performance through total quality management (TQM): strategies for competitive advantage", Procedia-Social and Behavioral Sciences, Vol. 24, pp. 1650-1662.

Agus, A., Suresh, K. and Sharifah Latifah, S.K. (2000), "The structural impact of TQM on financial performance relative to competitors through customer satisfaction: an empirical study of Malaysian manufacturing companies", Total Quality Management, Vol. 11 Nos 4/5, pp. 805-816. 
Ahire, S.L., Golhar, D.Y. and Waller, M.A. (1996), "Development and validation of TQM implementation constructs", Decision Sciences, Vol. 27, pp. 23-56.

Anderson, J.C., Rungtusanatham, M. and Schroeder, R.G. (1994), "A theory of quality management underlying the Deming management method", The Academy of Management Review, Vol. 19 No. 3, pp. 472-509.

Antony, J., Leung, K., Knowles, G. and Gosh, S. (2002), "Critical success factors of TQM implementation in Hong Kong industries", International Journal of Quality \& Reliability Management, Vol. 19 No. 5, pp. 551-566.

Atwal, G. and Williams, A. (2009), "Luxury brand marketing - the experience is everything!", Journal of Brand Management, Vol. 16 Nos 5/6, pp. 338-346.

Benson, P.G., Saraph, J.V. and Schroeder, R.G. (1991), "The effects of organizational context on quality management: an empirical investigation”, Management Science, Vol. 37 No. 9, pp. 1107-1124.

Berman, S.L., Wicks, A.C., Kotha, S. and Jones, T.M. (1999), "Does stakeholder orientation matter? The relationship between stakeholder management models and firm financial performance", Academy of Management Journal, pp. 488-506.

Brun, A. (2011), "Critical success factors of six sigma implementations in Italian companies", International Journal of Production Economics, Vol. 131 No. 1, pp. 158-164.

Brun, A. and Castelli, C. (2008), "Supply chain strategy in the fashion industry: developing a portfolio model depending on product, retail channel and brand", International Journal of Production Economics, Vol. 116 No. 2, pp. 169-181.

Brun, A. and Moretto, A. (2012), "Contract design and supply chain management in the luxury jewellery industry", International Journal of Retail and Distribution Management, Vol. 40 No. 8, pp. 607-628.

Brun, A., Caniato, F., Caridi, M., Castelli, C., Miragliotta, G., Ronchi, S., Sianesi, A. and Spina, G. (2008), "Logistics and supply chain management in luxury fashion retail: an empirical investigation of Italian firms", International Journal of Production Economics, Vol. 114 No. 2, pp. 554-570.

Cagnazzo, L., Taticchi, P. and Brun, A. (2010), "The role of performance measurement systems to support quality improvement initiatives at supply chain level", International Journal of Productivity and Performance Management, Vol. 59 No. 2, pp. 163-185.

Caniato, F., Caridi, M., Castelli, C. and Crippa, L. (2008), "Demand and retail management in luxury fashion industries", Research Journal of Textile and Apparel, Vol. 12 No. 3, pp. 65-76.

Caniato, F., Caridi, M., Castelli, C. and Golini, R. (2009), "A contingency approach for SC strategy in the Italian luxury industry: do consolidated models fit?", International Journal of Production Economics, Vol. 120 No. 1, pp. 176-189.

Caniato, F., Caridi, M., Castelli, C. and Golini, R. (2011), "Supply chain management in the luxury industry: a first classification of companies and their strategies", International Journal of Production Economics, Vol. 133 No. 2, pp. 622-633.

Castelli, C. and Brun, A. (2010), "Alignment of retail channel in the fashion supply chain - an empirical study of Italian fashion retailers", International Journal of Retail and Distribution Management, Vol. 38 No. 1, pp. 24-44.

Corbett, L.M. and Rastrick, K.N. (2000), "Quality performance and organizational culture: a New Zealand study”, International Journal of Quality \& Reliability Management, Vol. 17 No. 1, pp. 14-26.

Croom, S., Romano, P. and Giannakis, M. (2000), "Supply chain management: an analytical framework for critical literature review", European Journal of Purchasing and Supply Management, Vol. 6 No. 1, pp. 67-83.

De Araujo, M. (1997), "Management trends in textiles and clothing", Journal of Fashion Marketing and Management, Vol. 1 No. 3, pp. 260-273. 
Eisenhardt, K.M. (1989), "Building theories from case study research", Academy of Management Review, Vol. 14 No. 4, pp. 532-550.

Fawcett, S., Ellram, L. and Ogden, J. (2006), Upper Saddle River, Prentice-Hall, NJ.

Flynn, B.B. and Flynn, E.J. (2005), "Synergies between supply chain management and quality management: emerging implications", International Journal of Production Research, Vol. 43 No. 16, pp. 3421-3436.

Flynn, B.B., Schroeder, R.G. and Sakakibara, S. (1994), "A framework for quality management research and an associated measurement instrument", Journal of Operations Management, Vol. 11, pp. 339-366.

Flyvbjerg, B. (2006), "Five misunderstandings about case-study research", Qualitative Inquiry, Vol. 12 No. 2, pp. 219-245.

Forker, L.B., Mendez, D. and Hershauer, J.C. (1997), "Total quality management in the supply chain: what is its impact on performance?", International Journal of Production Research, Vol. 35 No. 6, pp. 1681-1702.

Foster, S.T. (2008), “Towards an understanding of supply chain quality management”, Journal of Operations Management, Vol. 26 No. 4, pp. 461-467.

Fryer, K.J., Antony, J. and Douglas, A. (2007), "Critical success factors of continuous improvement in the public sector: a literature review and some key findings", The TQM Magazine, Vol. 19 No. 5, pp. 497-517.

Garvin, D.A. (1988), Managing Quality: The Strategic and Competitive Edge, The Free Press, New York, NY.

Harland, C.M. (1996), "Supply chain management: relationships, chains and networks", British Journal of Management, Vol. 7 No. s1, pp. 63-81.

Irani, Z., Beskese, A. and Love, P.E.D. (2004), "Total quality management and corporate culture: constructs of organisational excellence", Technovation, Vol. 24 No. 8, pp. 643-650.

Kannan, V.R. and Tan, K.C. (2005), "Just in time, total quality management, and supply chain management: understanding their linkages and impact on business performance", The International Journal of Management Science, Vol. 33 No. 2, pp. 153-162.

Kaynak, H. (2003), "The relationship between total quality management practices and their effects on firm performance", Journal of Operations Management, Vol. 21, pp. 405-435.

Kaynak, H. and Hartley, J.L. (2008), "A replication and extension of quality management into the supply chain”, Journal of Operations Management, Vol. 26 No. 4, pp. 468-498.

Kuei, C.H., Madu, C.N. and Lin, C. (2008), "Implementing supply chain quality management", Total Quality Management, Vol. 19 No. 11, pp. 1127-1141.

Larsson, R. and Lubatkin, M. (2001), "Achieving acculturation in mergers and acquisitions: an international case survey”, Human Relations, Vol. 54 No. 12, pp. 1573-1607.

Lewis, W.G., Pun, K.F. and Lalla, T.R.M. (2006), "Exploring soft versus hard factors for TQM implementation in small and medium-sized enterprises", International Journal of Productivity and Performance Management, Vol. 55 No. 7, pp. 539-554.

Lincoln, Y.S. and Guba, E.G. (1985), "Establishing trustworthiness", Naturalistic Inquiry, Sage Publications, Newbury Park, CA, pp. 289-331.

Luzzini, D. and Ronchi, S. (2010), "Purchasing management in the luxury industry: organization and practices", Operations Management Research, Vol. 3 Nos 1/2, pp. 7-21.

McCracken, G. (1988), The Long Interview, Sage Publications, Newbury Park, CA.

Mar Fuentes-Fuentes, M., Albacete-Sáez, C.A. and Lloréns-Montes, F.J. (2004), "The impact of environmental characteristics on TQM principles and organizational performance", Omega, Vol. 32 No. 6, pp. 425-442. 
Maull, R., Brown, P. and Cliffe, R. (2001), "Organisational culture and quality improvement", International Journal of Operations \& Production Management, Vol. 21 No. 3, pp. 302-326.

Mentzer, J.T., DeWitt, W., Keebler, J.S., Min, S., Nix, N.W., Smith, C.D. and Zacharia, Z.G. (2001), "What is supply chain management", in Mentzer, J.T. (Ed.), Supply Chain Management, Sage, Thousand Oaks, CA, pp. 1-25.

Moore, C.M. and Birtwistle, G. (2004), "The Burberry business model”, International Journal of Retail and Distribution Management, Vol. 8, pp. 412-422.

Nair, A. (2006), "Meta-analysis of the relationship between quality management practices and firm performance-implications for quality management theory development", Journal of Operations Management, Vol. 24, pp. 948-975.

Naor, M., Goldstein, S.M., Linderman, K.W. and Schroeder, R.G. (2008), "The role of culture as driver of quality management and performance: infrastructure versus core quality practices”, Decision Sciences, Vol. 39 No. 4, pp. 671-702.

Popp, A., Ruckman, J. and Rowe, H.D. (2000), "Quality in international clothing supply chains: a preliminary study", Journal of Fashion Marketing and Management, Vol. 4 No. 2, pp. 140-161.

Popp, A., Ruckman, J.E. and Rowe, H. (2001), "Quality in international clothing supply chains: cost versus quality", Journal of Fashion Marketing and Management, Vol. 5 No. 4, pp. 275-288.

Prajogo, D.I. and Sohal, A.S. (2006), "The relationship between organization strategy, total quality management (TQM), and organization performance - the mediating role of TQM", European Journal of Operational Research, Vol. 168 No. 1, pp. 35-50.

Rad, A.M.M. (2006), "The impact of organizational culture on the successful implementation of total quality management”, The TQM Magazine, Vol. 18 No. 6, pp. 606-625.

Robinson, C.J. and Malhotra, M.K. (2005), "Defining the concept of supply chain quality management and its relevance to academic and industrial practice", International Journal of Production Economics, Vol. 96 No. 3, pp. 315-337.

Rockart, J.F. (1979), "Chief executives define their own data needs”, Harvard Business Review, March-April, p. 81.

Rungtusanatham, M., Forza, C., Filippini, R. and Anderson, J.C. (1998), “A replication study of a theory of quality management underlying the Deming method: insights from an Italian context”, Journal of Operations Management, Vol. 17, pp. 77-95.

Sadikoglu, E. and Zehir, C. (2010), "Investigating the effects of innovation and employee performance on the relationship between total quality management practices and firm performance: an empirical study of Turkish firms", International Journal of Production Economics, Vol. 127 No. 1, pp. 13-26.

Samson, D. and Terziovski, M. (1999), "The relationship between total quality management practices and operational performance", Journal of Operations Management, Vol. 17, pp. 393-409.

Santos-Vijande, M.L. and Álvarez-González, L.I. (2007), "Innovativeness and organizational innovation in total quality oriented firms: the moderating role of market turbulence", Technovation, Vol. 27 No. 9, pp. 514-532.

Savino, M., Brun, A. and Riccio, C. (2011), "Integrated system for maintenance and safety management through FMECA principles and fuzzy inference engine", European Journal of Industrial Engineering, Vol. 5 No. 2, pp. 132-169.

Seuring, S.A. (2008), "Assessing the rigor of case study research in supply chain management", Supply Chain Management: An International Journal, Vol. 13 No. 2, pp. 128-137. 
Sila, I. and Ebrahimpour, M. (2003), "Examination and comparison of the critical factors of total quality management (TQM) across countries", International Journal of Production Research, Vol. 41 No. 2, pp. 235-268.

Sohal, A.S. and Terziovski, M. (2000), "TQM in Australian manufacturing: factors critical to success", International Journal of Quality \& Reliability Management, Vol. 17 No. 2, pp. 158-168.

StudyMode.com (2012), "Luxury industry in France", available at: www.studymode.com/essays/ Luxury-Industry-In-France-924930.html (accessed 2, 2012).

Vickers, S.J. and Renand, F. (2003), "The marketing of luxury goods: an exploratory study - three conceptual dimensions", The Marketing Review, Vol. 3 No. 4, pp. 459-478.

Vickery, S., Droge, C. and Germain, R. (1999), "The relationship between product customization and organizational structure", Journal of Operations Management, Vol. 17 No. 4, pp. 377-391.

Yin, R.K. (1994), Case Study Research: Design and Methods. Applied Social Research Methods Series, Vol. 5. Sage Publications.

Yin, R.K. (2003), Case Study Research: Design and Methods, 3rd ed., Sage Publications, Thousand Oaks, CA.

Zhao, X., Yeung, A.C.L. and Lee, T.S. (2004), "Quality management and organizational context in selected service industries of China”, Journal of Operations Management, Vol. 22 No. 6, pp. 575-587.

\section{Appendix 1}

\begin{tabular}{|c|c|c|c|c|}
\hline Company & $\begin{array}{l}\text { Level of } \\
\text { centralisation }\end{array}$ & $\begin{array}{l}\quad \text { Structure } \\
\text { Position in the } \\
\text { organisational chart }\end{array}$ & Grouping criteria & $\begin{array}{l}\text { Role } \\
\text { Quality } \\
\text { control }\end{array}$ \\
\hline $\begin{array}{l}\text { Louis } \\
\text { Vuitton }\end{array}$ & Full-time & Model C & By product family & $\begin{array}{l}\text { Systematic } \\
\text { Manual }\end{array}$ \\
\hline Hermes & Part-time & Model D & By product family & No control \\
\hline Chanel & Full-time & Model A & By area & $\begin{array}{l}\text { Statistical } \\
\text { Automated }\end{array}$ \\
\hline Givenchy & Full-time & Model C & By area & $\begin{array}{l}\text { Statistical systematic } \\
\text { for cosmetics } \\
\text { Automated }\end{array}$ \\
\hline Dior & Full-time & Model A & By area & $\begin{array}{l}\text { Statistical } \\
\text { Automated }\end{array}$ \\
\hline Baccarat & Full-time & Model C & By area & $\begin{array}{l}\text { Systematic } \\
\text { Automated }\end{array}$ \\
\hline $\begin{array}{l}\text { Moët \& } \\
\text { Chandon }\end{array}$ & Full-time & Model B & By area & $\begin{array}{l}\text { Systematic } \\
\text { Automated }\end{array}$ \\
\hline Cartier & Part-time & Model D & By approach & $\begin{array}{l}\text { Statistical for } \\
\text { standardised products } \\
\text { systematic for fine } \\
\text { jewellery } \\
\text { Automated }\end{array}$ \\
\hline
\end{tabular}

Table AI. Organisation of QM department in the sample 


\section{Appendix 2}

\begin{tabular}{|c|c|c|c|c|c|}
\hline Company & Formalisation & $\begin{array}{l}\text { Make } \\
\text { Application } \\
\text { of TQM }\end{array}$ & $\begin{array}{l}\text { Source } \\
\text { Adoption of } \\
\text { supplier quality } \\
\text { insurance }\end{array}$ & $\begin{array}{l}\text { Type of } \\
\text { network }\end{array}$ & $\begin{array}{l}\text { ver } \\
\text { Level of } \\
\text { control over } \\
\text { the network }\end{array}$ \\
\hline Louis Vuitton & $\begin{array}{l}\text { Voluntary } \\
\text { certification } \\
\text { (ISO 14000) }\end{array}$ & $\begin{array}{l}\text { Not formalised } \\
\text { (high attention) }\end{array}$ & $\begin{array}{l}\text { No adoption (but } \\
\text { high attention) }\end{array}$ & $\begin{array}{l}\text { Owned } \\
\text { network }\end{array}$ & High control \\
\hline Hermes & $\begin{array}{l}\text { None } \\
\text { None }\end{array}$ & $\begin{array}{l}\text { Not formalised } \\
\text { (low attention) }\end{array}$ & $\begin{array}{l}\text { No adoption } \\
\text { (trust) }\end{array}$ & $\begin{array}{l}\text { Owned } \\
\text { network }\end{array}$ & Autonomous \\
\hline Chanel & $\begin{array}{l}\text { Industry } \\
\text { certification } \\
\text { (ICH-Q10) } \\
\text { Manual }\end{array}$ & $\begin{array}{l}\text { Not formalised } \\
\text { (high attention) }\end{array}$ & $\begin{array}{l}\text { Adoption (high } \\
\text { level) }\end{array}$ & $\begin{array}{l}\text { Multi-brand } \\
\text { network }\end{array}$ & Low control \\
\hline Givenchy & $\begin{array}{l}\text { Industry } \\
\text { certification } \\
\text { (ISO 22716) } \\
\text { Procedure }\end{array}$ & $\begin{array}{l}\text { Not formalised } \\
\text { (high attention) }\end{array}$ & $\begin{array}{l}\text { Adoption } \\
\text { (medium level) }\end{array}$ & $\begin{array}{l}\text { Multi-brand } \\
\text { network }\end{array}$ & Low control \\
\hline Dior & $\begin{array}{l}\text { None } \\
\text { N.A. }\end{array}$ & $\begin{array}{l}\text { Not formalised } \\
\text { (high attention) }\end{array}$ & $\begin{array}{l}\text { Adoption (high } \\
\text { level) }\end{array}$ & $\begin{array}{l}\text { Multi-brand } \\
\text { network }\end{array}$ & Low control \\
\hline Baccarat & $\begin{array}{l}\text { Country } \\
\text { certification } \\
\text { Procedure } \\
\text { and manual }\end{array}$ & $\begin{array}{l}\text { Not formalised } \\
\text { (medium } \\
\text { attention) }\end{array}$ & $\begin{array}{l}\text { No Adoption } \\
\text { (statistical } \\
\text { control) }\end{array}$ & $\begin{array}{l}\text { Owned and } \\
\text { multi-brand } \\
\text { network }\end{array}$ & Low control \\
\hline $\begin{array}{l}\text { Moët \& } \\
\text { Chandon }\end{array}$ & $\begin{array}{l}\text { Voluntary } \\
\text { certification } \\
\text { (ISO 22000; } \\
\text { PHS 14000) } \\
\text { Country } \\
\text { certification } \\
\text { Manual }\end{array}$ & Not implemented & $\begin{array}{l}\text { No adoption } \\
\text { (high attention) }\end{array}$ & $\begin{array}{l}\text { Multi-brand } \\
\text { network }\end{array}$ & Low control \\
\hline Cartier & $\begin{array}{l}\text { Personal } \\
\text { certification } \\
\text { Procedure }\end{array}$ & $\begin{array}{l}\text { Not formalised } \\
\text { (high attention) }\end{array}$ & $\begin{array}{l}\text { Adoption (high } \\
\text { level) }\end{array}$ & $\begin{array}{l}\text { Owned } \\
\text { network }\end{array}$ & Low control \\
\hline
\end{tabular}

\section{About the authors}

Dr Alessandro Brun holds a Master Degree with Honours in Production and Management Engineering and $\mathrm{PhD}$ on the same subject. He is a teacher of quality management at the Politecnico di Milano, and Director of training programmes on Six Sigma at the MIP-Politecnico di Milano. His main research streams are related to supply chain management and operational improvements in manufacturing and service industries, with a particular focus on luxury goods and services.

Antonella Moretto is a $\mathrm{PhD}$ Candidate at the Politecnico di Milano. She graduated in management, economics and industrial engineering at the Politecnico di Milano discussing a thesis about the development of a value assessment model to quantify the eProcurement benefits. Her research interests are in the fields of supply chain management and supply chain collaboration in the international context for fashion companies. Antonella Moretto is the corresponding author and can be contacted at: antonella.moretto@mail.polimi.it 